December 2009

\title{
Darfur: Strategic Victimhood Strikes Again?
}

Alan J. Kuperman

Follow this and additional works at: https://digitalcommons.usf.edu/gsp

\section{Recommended Citation}

Kuperman, Alan J. (2009) "Darfur: Strategic Victimhood Strikes Again?," Genocide Studies and Prevention: An International Journal: Vol. 4: Iss. 3: Article 3.

Available at: https://digitalcommons.usf.edu/gsp/vol4/iss3/3

This Articles is brought to you for free and open access by the Open Access Journals at Digital Commons @ University of South Florida. It has been accepted for inclusion in Genocide Studies and Prevention: An International Journal by an authorized editor of Digital Commons @ University of South Florida. For more information, please contact digitalcommons@usf.edu. 


\title{
Darfur: Strategic Victimhood Strikes Again?
}

\author{
Alan J. Kuperman \\ LBJ School of Public Affairs, University of Texas, Austin
}

\begin{abstract}
Although most humanitarians advocate more international intervention in Darfur, some analysts urge the opposite on grounds that intervention has backfired due to the problem of moral hazard. These contrarians argue that the expectation of benefiting from intervention is what emboldens Darfur's rebels to fight, which provokes state-sponsored retaliation against their perceived civilian supporters, thereby exacerbating and prolonging the humanitarian emergency. This article tests the moralhazard hypothesis against four other potential explanations for why Darfur's militants launched and perpetuated their rebellion despite being unable to protect their civilians from genocidal retaliation. The evidence indicates that moral hazardthe expectation of humanitarian intervention-increased both the magnitude and duration of Darfur's rebellion, and therefore the retaliation it provoked against civilians. Competing hypotheses are less plausible but cannot be ruled out completely based on available evidence. The article explores the policy implications for intervention in Darfur and other humanitarian emergencies, and offers suggestions for further research.
\end{abstract}

Key words: Darfur, Sudan, humanitarian, intervention, moral hazard, genocide

\section{Introduction}

For over five years, Western media, politicians, and non-governmental organizations have criticized the relatively modest level of international intervention in Darfur, a region of northwest Sudan that was obscure until war broke out in 2003. Nearly all of these critics argue that intervention has been inadequate in light of the scope of violence and suffering, which includes 3 million displaced persons and a death toll estimated up to half a million. But a small band of contrarians, including me, has argued that the problem is essentially the opposite: the prospect of more intervention. We acknowledge that violence has been perpetrated mainly by Sudan's army and state-supported Arab Janjaweed militias against villages accused of supporting African tribal rebels, and that intervention to date has been inadequate to protect civilians. But we contend that the prospect of luring Western intervention to tip the balance of power in their favor is what drives the rebels to fight a war that they cannot win on their own. If not for the prospect of such intervention, we argue, the rebels long ago would have sued for peace, which the government would have accepted, thereby ending the violence. Thus, we conclude, Western calls for intervention have backfired, perpetuating fighting in Darfur and the resultant suffering of its civilians.

If correct, this radical hypothesis has important implications for intervention in Sudan and elsewhere. Indeed, I have argued previously for redesigning intervention policy so as not to reward rebels unless state retaliation is grossly disproportionate, and for promoting instead the cause of nonviolent protest movements. ${ }^{1}$ The hypothesis, however, has yet to be tested rigorously in Darfur, so this article represents a first attempt to do so. It starts by summarizing the recent literature on the "moral hazard

Alan J. Kuperman, "Darfur: Strategic Victimhood Strikes Again?” Genocide Studies and Prevention 4, 3 (December 2009): 281-303. (C) 2009 Genocide Studies and Prevention. doi:10.3138/ gsp.4.3.281 
of humanitarian intervention." Next, it lays out a methodology to assess the hypothesis in Darfur, and then conducts such a test. The final section analyzes the policy implications for intervention in Darfur and beyond, and offers recommendations for further research.

\section{Moral Hazard and Its Critics}

In economics, "moral hazard" is the phenomenon in which the provision of insurance against risk unintentionally encourages the insured to act irresponsibly or fraudulently based on the expectation that any resulting short-term loss will be compensated by the subsequent insurance payout. Analogously, I have argued that the emerging norm of humanitarian intervention, now subsumed in the concept of the "Responsibility to Protect" as explained below, inadvertently encourages rebellion by members of sub-state groups that are vulnerable to retaliation by increasing their expectation of success and decreasing their expected cost. ${ }^{2}$ Moral hazard can be caused by a wide range of humanitarian intervention, not confined to military deployment but including "any international action that is primarily motivated by the humanitarian desire to protect civilian targets of state violence," 3 if that intervention also encourages rebellion. This includes rhetorical condemnation and economic sanctions against states, diplomatic recognition of secessionist entities, and covert military assistance to rebels. When such intervention encourages members of a sub-state group to launch or perpetuate an armed challenge, the state often retaliates against the group's civilians. Intervention ultimately may assist the rebels to attain their political goals but typically is too late or inadequate to protect the civilians from state retaliation. Thus, the emerging norm sometimes backfires by helping to cause the tragic outcomes that it intends to prevent. I have demonstrated this phenomenon in two cases from the Balkans in the 1990s, Bosnia and Kosovo, by testing the hypothesis against competing explanations based on evidence, including interviews with the leaders of each armed challenge. ${ }^{4}$

Some advocates of the Responsibility to Protect norm claim that it is more expansive and less belligerent than the older concept of humanitarian intervention, because it emphasizes first the responsibility of states to protect their own people and second the responsibility of other states to offer consensual assistance. Only failing those efforts does the new concept contemplate more intrusive international measures, and it explicitly relegates military intervention to a last resort. In reality, however, this ostensibly innovative concept merely codifies the practice of humanitarian intervention as it has emerged since 1991. Typically, when civilians have been threatened by a state, the international community has first exhorted the state to desist, next offered assistance ranging from mediation to peacekeeping, then imposed non-military coercive measures such as economic sanctions, and only as a last resort contemplated non-consensual military intervention. This escalatory ladder of intervention, ranging from least to most intrusive, is driven by the dual objectives of providing humanitarian protection while minimizing the violation of traditional state sovereignty. The attempted "re-branding" of the intervention norm as the Responsibility to Protect may have broadened its nominal support among developing states but has neither altered the substance of the emerging norm nor mitigated the moral-hazard problem. ${ }^{5}$

In a previous essay, I suggested reforming the practice of humanitarian intervention in five ways. First, do not help sub-state rebels unless state retaliation is grossly disproportionate, so that both sides have incentive to restrain their violence. Second, deliver humanitarian aid to affected civilians in ways that minimize the benefit to 
rebels, such as via transportation corridors and displaced-person camps that are patrolled to exclude militants or at least their weapons. Third, expend substantial resources to persuade states to address the legitimate grievances of non-violent domestic groups, to further discourage rebellion. Fourth, do not coerce states to surrender territory or authority to a domestic opposition unless and until a robust peacekeeping force is deployed to protect against the potential violent backlash. Fifth, do not falsely claim humanitarian motives for interventions that are driven primarily by other objectives-such as securing resources, fighting terrorism, or preventing nuclear proliferation-because this can inadvertently increase the expectation of sub-state groups elsewhere that they can attract intervention by provoking a humanitarian emergency. ${ }^{6}$

Timothy Crawford has refined the theory by specifying more precisely the potential causes and consequences of moral hazard. ${ }^{7}$ First, he differentiates four possible sources of expectations within a sub-state group about prospective intervention: recent signals by a potential intervener regarding the specific case; recent interventions elsewhere, especially nearby; older interventions in the region; or the more general emerging norm of humanitarian intervention. Second, he differentiates two putative effects: the initiation of an armed challenge and the perpetuation of such a rebellion. He argues deductively that moral hazard should be most intense when third parties signal their intention to intervene in a specific case, and that moral hazard is more likely to perpetuate than to initiate a rebellion.

Other critics of the moral-hazard theory dispute or refine its claims about the Balkans. Jon Western argues that the armed challenges in Bosnia and Kosovo were triggered not by hopes of intervention but by an escalatory spiral of grievance and insecurity. ${ }^{8}$ Arman Grigorian insists that the US threat of intervention in Kosovo was motivated not by humanitarian concern but by a desire for vengeance against Serbian leader Slobodan Milosevic. ${ }^{9}$ In that same case, Harrison Wagner emphasizes that the expectation of intervention compelled the state to perpetrate ethnic cleansing in anticipation of, but prior to, the ultimate rebel escalation anticipated by the theory. ${ }^{10}$

\section{Moral Hazard in Darfur?}

Since 2004, several Western analysts have argued that calls for intervention in Darfur have backfired by emboldening the rebels, thereby prolonging that region's conflict and the resultant suffering of its civilians. But these contrarians have cited little evidence in support of their claims and typically have failed to distinguish between the outbreak and perpetuation of rebellion. None of these critics, including me, heretofore has tested the moral-hazard hypothesis against other potential explanations for the rebellion in Darfur. ${ }^{11}$

A rigorous examination of moral hazard in Darfur entails three steps. First, the hypothesis should be tested against other plausible explanations for the rebellion. Next, if moral hazard is determined to play some causal role, that role should be pinpointed as either triggering the rebellion, perpetuating it, or both. Finally, the sources of the rebels' expectations about intervention should be specified, in accordance with the critiques of Crawford and Grigorian. All three steps are susceptible to the casestudy inferential method of "process-tracing," by positing the evidence that would prove or disprove each hypothesis and then searching for such proof in primary and secondary sources. ${ }^{12}$

As I have argued previously, there are only five plausible reasons, including moral hazard, why members of a sub-state group would launch and perpetuate a rebellion 
Table 1: Possible Explanations for Suicidal Rebellions

\begin{tabular}{ll}
\hline 1 & Do not expect retaliation \\
2 & Perceive victimization as inevitable \\
3 & Expect victory without intervention \\
4 & Expect intervention to enable victory \\
5 & Not driven by strategic calculus \\
\hline
\end{tabular}

that provokes massive state retaliation against the group's civilians, which I call "suicidal rebellion" (Table 1) ${ }^{13}$ First, the militants may not expect the state's reaction, which could explain the initial rebellion although not its perpetuation in the face of retaliation. Second, prior to the rebellion, these militants may expect the state inevitably to attack the group's civilians, so that they perceive nothing to lose by rebelling even without an expectation of victory. Third, the militants may expect the rebellion to succeed without intervention and may view the retaliation against their civilians as an acceptable cost. Fourth - the moral hazard explanation - the militants may rebel only because they expect state retaliation to trigger international intervention that enables them to prevail at an acceptable cost. Finally, the rebellion may be driven by something other than strategic calculus, such as frustration. Each hypothesis could be confirmed by evidence that either supported it or disproved all the others.

\section{Rebellion, Retaliation, and Resistance to Compromise}

Sudan has endured multiple civil wars since independence in 1956, often arising from challenges to the traditional Arab Islamic elite in the northern capital of Khartoum who monopolize power and wealth. The first war, pitting Khartoum against racially and religiously distinct rebels from the south, persisted from 1956 to 1972. That fight resumed in 1983 and raged until the July 2002 Machakos Protocol, which laid out principles of a power-dividing settlement that subsequently was codified in a January 2005 Comprehensive Peace Agreement. The north-south wars were brutal, as the government employed its armed forces and allied militias in a scorched-earth counterinsurgency against rebel areas, inflicting an estimated 2 million deaths, many from war-induced deprivation.

In Darfur, conflict has multiple roots that stretch back more than four decades, including the spillover of the war between neighboring Libya and Chad; land disputes between settled tribes and nomadic Arab pastoralists, exacerbated by increasing desertification; an Arab supremacist movement sponsored by Libya; political reforms that disempowered local tribes; and monopolization of power and wealth by Khartoum. ${ }^{14}$ Despite widespread grievances and a history of low-level conflict, however, Darfur avoided full-scale civil war until 2003. Indeed, in 1991, when southern Sudan's rebels attempted to spread war to Darfur by sponsoring an invasion from neighboring Kordofan province, the outsiders received little local support and were quickly defeated by Sudan's army and an allied Arab militia. ${ }^{15}$

Starting around 1999, however, militants among Darfur's largest African tribes prepared for rebellion. In that year, Masalit militants traveled to Eritrea to be trained by rebels from southern Sudan. In 2000, Fur rebels set up training camps in central Darfur and extracted taxes from the local populace. In 2001, Masalit and Fur militants traveled to southern Sudan to gain combat skills by fighting alongside the rebels there. Then, in February 2002, Zaghawa, Fur, and Masalit rebels launched their first 
joint attack, under the rubric of the Darfur Liberation Army, burning an army garrison in central Darfur and seizing arms. A year later, these militants launched a fullblown rebellion under a new name: the Sudan Liberation Army (SLA). Days later, a second Darfur rebel group, comprising mainly Zaghawa and closely tied to the Islamist leader Hassan Turabi, who recently had been purged by the Khartoum regime, announced itself as the Justice and Equality Movement (JEM). ${ }^{16}$ The SLA had more grass-roots support and concentrated its demands on Darfur, while the JEM enjoyed greater resources from its external Islamist connections and announced a nationwide reform agenda, in keeping with Turabi's political aspirations.

The SLA's first major attack, in February 2003, killed 200 soldiers in Golu, in western Darfur. More spectacularly, in April 2003, both rebel groups attacked two army outposts in central and southern Darfur, killing dozens of soldiers, destroying several fixed-wing aircraft and helicopters, and capturing a base commander. Over the next four months, the rebels killed hundreds more soldiers in three attacks on north Darfur. ${ }^{17}$

Sudan's government responded initially by trying to negotiate with the rebels. In March 2003, Khartoum dispatched North Darfur's governor to London to forge a deal with JEM leader Khalil Ibrahim, but "the governor came back empty-handed." Additional overtures by government officials later that spring also failed, reportedly due to opposition from hardliners on both sides. ${ }^{18}$ It is difficult to assess Khartoum's sincerity in these early talks, but it is notable that the government's first response to the rebellion was to negotiate rather than to deploy overwhelming force. Only after four months of rebel attacks and failed peace talks did Khartoum, in June 2003, switch to a devastatingly violent counterinsurgency strategy, combining the army, popular defense forces, aerial bombardment, and local Janjaweed Arab militias to attack hundreds of villages suspected of supporting the rebels. Typically, the attacks started with imprecise bombing from aircraft to sow terror, after which militias arrived on horseback to loot and then burn the villages, often killing or raping a few residents and generally compelling most of the rest to flee. By late 2003, thousands of Darfur's Africans had been killed, while hundreds of thousands were displaced from their homes. International relief organizations began delivering aid in 2003 to the displaced in camps in Darfur and neighboring Chad, and African Union (AU) monitors entered Darfur in 2004. But persistent low-level fighting has perpetuated the humanitarian deprivation of many Darfuris. Over the course of the war, thousands have been killed directly by fighting, while tens of thousands of additional deaths are attributed to higher than normal mortality inside and outside the camps. ${ }^{19}$

Despite the rebels' inability to defeat the government forces and militia or to defend civilians against retaliation, they repeatedly refused to test the sincerity of the government's overtures to end the fighting, which potentially could have alleviated humanitarian suffering via negotiated compromise. Some critics of Sudan's regime claim that it does not sincerely want peace in Darfur because a power-sharing deal would weaken the central government prior to south Sudan's secession referendum in 2011, increasing the risk of the country's disintegration. More likely, however, Khartoum seeks to maximize its military potential prior to the 2011 referendum, in order to coerce the south not to vote for secession or otherwise to defeat it. In that light, Khartoum has a very strong incentive to end the war in Darfur, so it can free up its security forces to deter or win a renewed war in the south.

The sincerity of Khartoum's peace offers in Darfur remains unknown because the rebels have refused to explore them in good faith. In November 2003, the Sudan Liberation Movement (SLM), the political arm of the SLA, abandoned peace talks in 
Chad. The following month, despite rapidly diminishing prospects on the battlefield and mounting humanitarian suffering, the rebels actually increased their demands, blocking any chance for peace. ${ }^{20}$ From April to July 2004, both main rebel groups refused to attend peace talks in Chad and Ethiopia. ${ }^{21}$ In December 2004, the SLA failed to attend peace talks in Nigeria. In September 2005, following a split in the SLA, the representative of the Zaghawa wing failed to attend another round of those talks. In November 2005, the rebels stalled negotiations by unrealistically demanding 90 percent of the positions in local government. (Even under the north-south peace deal, negotiated by rebels who were much stronger, the government retained 70 percent of such positions.) Finally, in May 2006, when Sudan's government signed the Darfur Peace Agreement, brokered by the United States and the African Union, only the SLA's Zaghawa faction (led by Minni Minawi) signed, while the JEM (led by Khalil Ibrahim) and the SLA's Fur wing (led by Abdel Wahid) rejected it. ${ }^{22}$ As a result, the war continued, rebel factions splintered, Darfur descended into anarchy, and attacks mounted against relief organizations, which reacted by cutting back their operations, thereby increasing humanitarian suffering.

The puzzle addressed in this article is why the Darfur rebels, who could neither defeat the government nor defend civilians from retaliation, chose to launch and perpetuate a rebellion that provoked such massive violence against their own civilians, while persistently rejecting government overtures for a negotiated peace. This does not imply that the rebels bear primary responsibility for the violence, nor does it deny the legitimate grievances and aspirations of Darfur's African tribes, nor does it excuse as mere retaliation the crimes committed by Sudan's government forces and allied militias. Rather, the question is about motivation and strategy: Why did the rebels pursue a course that imposed such a high cost on the civilians that they purported to represent, if this course also offered little prospect of attaining their political goals through military success? A rigorous explanation also must address timing: Why did Darfur's rebels launch and perpetuate their armed challenge from 2003 onwards, when the region's African tribes had overwhelmingly rejected calls for rebellion since at least 1991 ?

\section{Hypothesis 1: Surprised by Retaliation?}

All available evidence contradicts the first hypothesis: that Darfur's rebels were surprised when their rebellion provoked widespread government retaliation against civilians. ${ }^{23}$ First, government authorities previously had issued explicit threats of such retaliation. On a visit to Darfur in November 2002, Sudan's vice-president Ali Osman Taha warned militants "not to repeat in your area the colonial error which has paralyzed Southern Sudan," because Darfur would "be pulled backward for many years." In March 2003, just days after the rebels' first major attack, the governor of south Darfur threatened that "if dialogue does not work in Darfur, the Army can solve the situation in 24 hours." 24

The rebels had every reason to perceive such threats as credible, given the government's nearly two decades of brutal response to previous rebellions in Sudan. During the north-south civil war, the government and its typically Arab militias targeted civilians throughout the south: in Bahr el Ghazal starting in 1986, Wau in 1988, Juba in 1992, the Nuba Mountains in 1992-1995 (the government aimed to relocate the entire Nuba population), and the upper Nile in 1998-2003. As Julie Flint and Alex DeWaal observe, when Sudan's government was faced with rebellion, "scorched earth, massacre, pillage, and rape were the norm." Darfur's rebels surely were aware of these preceding events elsewhere in Sudan, but they also had precedent in Darfur 
itself. In 1987, in retaliation for incursions by rebels from southern Sudan, Arab militias in southeast Darfur killed more than 1,000 Dinka civilians who had been displaced from the south and thus were perceived as rebel sympathizers. ${ }^{25}$ In 1991 , when southern rebels sponsored their invasion of Darfur, Sudan's army and allied militia "burned entire villages on suspicion of having welcomed" the invaders. In 1999, when the Khartoum regime crushed a low-intensity Masalit insurgency in west Darfur, government forces killed an estimated 2,000 and displaced more than 100,000. In 2001, when southern rebels launched an offensive toward Darfur from Bahr el Ghazal, government-allied Arab militias retaliated in that neighboring state with "indiscriminate attacks on civilians." ${ }^{26}$ Moreover, when the Darfur rebels launched their initial, small-scale operations in 2002, they provoked the Janjaweed's first significant attacks on Fur civilians in south Darfur in October 2002. By the end of that year, such retaliation had killed hundreds of civilians and burned hundreds of villages across Darfur, vividly illustrating the costs of rebellion well before Darfur's rebels escalated to the high-profile attacks of $2003 .^{27}$

The strongest evidence that Darfur's rebels expected their insurgency to provoke retaliation against the region's African tribes is that those tribes opposed the rebellion on precisely such grounds. When Fur militants attempted to recruit in 1999, according to Flint and de Waal, "the Masalit were hesitant to take action that might exacerbate their suffering. They had bitter recent experience of how any action, however small, could escalate." 28 Similarly, when Zaghawa militants in the late 1990s argued that rebellion was the best course, they "found that most Zaghawa disagreed." ${ }^{29}$ Even after the fighting started, according to field researchers Abdul-Jabbar Fadul and Victor Tanner, "many Darfurian intellectuals criticized the decision to take up arms against the government. The brutality of Khartoum's reaction was predictable, they argued." 30

If any rebels failed to anticipate such retaliation prior to their first large attacks of early 2003, they could not have maintained that wishful thinking for long. By June 2003, Khartoum had reinstalled in Darfur the notorious leader of the Janjaweed, Musa Hilal, whom the government had exiled the previous year in a failed effort to conciliate the African tribes. During the next four months, the Janjaweed expanded its attacks, initially targeting rebel strongholds in the region's northwest and then broadening to African villages elsewhere in Darfur. ${ }^{31}$ Sudan's president, Omar alBashir, issued a clear threat in January 2004: "We will use all available means, the army, the police, the mujahideen, the horsemen, to get rid of the rebellion." 32 In March 2004, a Janjaweed leader explicitly threatened atrocities if Masalit chiefs failed to seal the border with Chad against an exodus of refugees: "If you don't make this security, I will kill all your civilians." 33

Both before and after initiating their attacks, Darfur's rebel leaders had overwhelming reason to believe that rebellion would provoke massive retaliation against the region's African tribes. Failure to anticipate this cost cannot credibly explain either the launching or the perpetuation of their rebellion.

\section{Hypothesis 2: Nothing to Lose?}

Some claim that Khartoum and its allied Arab militias initiated a genocide plan against Darfur's African tribes prior to any revolt, thus explaining the rebellion as an act of self-defense by targets of violence. For example, Flint and DeWaal quote a Masalit rebel offering this justification in retrospect: "We had no choice but to organize. We were fighting for our lives." Such narratives assert that Darfur's Africans turned to rebellion because they "felt they had nothing left to lose." Fur militants 
offered this explanation when they began mobilizing in 1998: "The Arabs will not allow us to stay in our land unless we defend ourselves. It is a war of 'to be or not to be." 34 The SLA's founder, in July 2002, months prior to the first large-scale rebel attack, averred that the Fur people already were victims of "genocide." 35

But such claims raise several questions: Was genocide actually underway prior to the rebellion? If not, did Darfur's Africans nevertheless perceive that genocide was ongoing or impending? If not, then after the rebellion initially provoked retaliation, did Darfur's Africans come to believe that genocide was inevitable and therefore favor the rebellion on grounds that they now had nothing to lose? If not, then why did Darfur's rebel leaders falsely make such claims?

Without question, starting in the 1970s, Darfur harbored Arab militants who sought to usurp African land and political authority, and in the 1990s Khartoum increasingly supported them. Political reforms favored the Arabs, prompting some African tribes to resist violently, which in turn spurred attacks by Arab militias. These attacks concentrated on Masalit villages that were perceived to support the uprising of 1994-1999, and less frequently targeted the Fur or the Zaghawa. ${ }^{36}$ In 2000, Sudan's government bolstered Darfur's Janjaweed militias. The next year, Arab tribesmen killed seventy Zaghawa in a dispute over an important water resource, and the government defended the Arabs.

But Darfur experienced no genocide-by any reasonable definition of the word including that in the UN Convention-prior to the rebellion. The greatest violence, by the army in January 1999, was intended not to destroy civilians but to crush the Masalit insurgency, as evidenced by the fact that the army desisted after the insurgents were defeated. ${ }^{37}$ The government armed the Janjaweed in 2000 as a preventive and deterrent measure because a schism in Khartoum, combined with incipient rebel mobilization, prompted fears that the recently purged Islamist politician Turabi would organize a revolt from Darfur (as he soon did through the JEM). ${ }^{38}$

Nor did Darfur's African tribes believe that Sudan's government was committing genocide against them, or intended to, prior to the rebellion. Throughout this time, Darfur's African populace refused to support mobilization for a rebellion. The SLA's founder confesses that in the late 1990s when he sought to raise funds for rebellion in the face of such opposition, "I lied to the people"-falsely assuring them that their donations would be used only to defend against local Arab militants, not to attack the state. ${ }^{39}$

When Darfur's African rebels began training in 1999, and then escalated to their first joint attack in February 2002, the government supported vicious retaliation by local Arab militias. As early as April 2002, the militias attacked Masalit areas in north Darfur. In May 2002, Fur parliamentarians reported that 420 of their civilians had been killed in 181 attacks on 83 villages. During the final four months of that year, another 100 or more Fur civilians reportedly were killed. ${ }^{40}$ But this increased violence, provoked by the rebels' initial attacks, did not qualify remotely as genocide, and was not perceived as such by Darfur's African tribes, who continued to oppose rebellion. Even the Sudan Federal Democratic Alliance, which previously had mobilized Darfur's African tribes for armed defense, opposed the rebellion. The group's leader, an expatriate Fur living in London, "thought it would be counter-productive and withheld his support." 41

After the first year of war, which included the worst violence against African civilians, Darfur's African tribes still did not believe that the government planned to target them in the absence of rebellion. According to field surveys in north and west Darfur in June 2004, all groups regardless of ethnic or tribal affiliation "stated both 
their opposition to armed rebellion and their belief that the current violence escalated in response to the insurgency." Strikingly, most respondents were "supportive of the rebels' agenda for change," which underscores that they opposed the rebellion not over its stated goals but because they felt its violent means endangered rather than protected them. ${ }^{42}$

After two more years of displacement and humanitarian deprivation, in May 2006, Darfur's African civilians still favored ending the rebellion by embracing the Darfur Peace Agreement (DPA) that was signed by the government. Although two of the three rebel factions rejected the deal, a former Darfur government official reported soon afterward that "independent groups are the strongest supporters of the DPA because they ... believe that even a flawed peace deal is better than continuing the war." 43 Field researchers concur that the local populace supported the DPA because "Darfurians firmly believed that UN troops could and would bring an end to the violence" under the agreement. ${ }^{44}$ This demonstrates that as late as mid-2006, the rebellion still was not driven by any popular perception that government violence against civilians was inevitable.

A close analysis of these peace negotiations also suggests that the Fur faction of the SLA rejected the agreement for reasons other than security. This rebel faction initially had expressed concerns about the proposed security provisions, but on 14 May 2006 Khartoum accepted in writing the faction's two main security demands: enhanced rebel roles in both protecting the return of displaced persons and monitoring the disarmament of Arab militia. The leader of this rebel faction, Abdel Wahid, then declared the security provisions "acceptable." But he still rejected the agreement, citing not security concerns but other complaints about insufficient sharing of wealth and power, according to members of the African Union's mediation team. ${ }^{45}$ It is impossible to know whether the government would have honored its security commitments if all three rebel factions had signed the DPA, but it is noteworthy that the Fur faction did not cite mistrust of these commitments as the reason it rejected the deal, but rather its additional demands for wealth and power. This suggests that the rebellion, at least at this juncture, was motivated by something other than a fear of inevitable government violence.

Only after two of the three rebel factions rejected the DPA, causing Darfur to descend into anarchy starting in June 2006, did Darfuris begin to view violence as inevitable and thus a reason to embrace rebellion. According to field researchers, Darfur's African tribes still sought peace, but now "they believed that only force could achieve that for them." The same Darfuris who previously had opposed militancy now "believed armed rebellion was the only solution." 46 Thus, it is possible that the second hypothesis - the expectation of inevitable victimization-explains the insurgency after May 2006, but not during the preceding three and a half years of rebellion.

\section{Hypothesis 3: David Expects to Beat Goliath?}

The third possible explanation for the rebellion is that Darfur's African militants expected to defeat Sudan's army and allied Arab militias and thereby attain their political goals-without requiring humanitarian intervention-and viewed the expected retaliation against their civilians as an acceptable price. Such an expectation of victory seems implausible, in light of the weakness of Darfur's rebels, the relative strength of the Sudanese armed forces and Arab militias in Darfur, the Sudanese government's track record of brutal counterinsurgency, the failure of the better-armed southern Sudan rebels to defeat the army for nearly two decades, the advent in 1999 
of oil exports that provided new revenue for the army, and the army's availability to fight in Darfur because of a north-south peace process that relieved it of deployment requirements in the south. But history is replete with cases of optimistic miscalculation leading to war, ${ }^{47}$ so it is necessary to explore whether Darfur's rebels ever believed that they could win, even if they never actually stood a chance.

Darfur's rebels had three potential reasons for optimism prior to launching their rebellion. First, they had multiple sources of support: finance from their diaspora and Islamists; training in Eritrea and in southern Sudan; and weapons from these sources as well as from ethnic Zaghawa in the armies of Sudan, Chad, and Libya. The JEM enjoyed greater financing from its connections to Islamist sources and thus more reason for optimism on these grounds. ${ }^{48}$ Second, the rebels might have expected largescale defections from Sudan's security forces to tilt the balance of power in their favor. Since 1989, Khartoum successfully had recruited Darfur's African Muslims to wage "Jihad" against southern Sudan's Christian and animist rebels. But such recruits were much less likely to fight against fellow Darfuri African Muslims and might even jump to their side. Third, some of the SLA's Zaghawa rebels previously had tasted military victory, having fought successfully in Chad to bring Idriss Deby to power in 1990. ${ }^{49}$ Although Khartoum represented a far more formidable opponent, it is possible that these rebels' past success had bred overoptimism.

On the other hand, Darfur's rebels initially lacked the two most crucial requirements for an insurgency: reliable supply lines and a rear base. ${ }^{50}$ Based on geography, only Chad was optimally suited for either task. But until mid-2006, Chad honored a deal with Sudan not to support each other's rebels. Chad's President Deby not only rejected requests from Darfur's rebels for support starting in 2002, but in 2003 he even deployed 500 troops to Sudan to help fight against the rebels. ${ }^{51}$ Some of Chad's soldiers individually may have provided unauthorized support for their Zaghawa brethren in Darfur prior to 2006, but Chad's government denied the rebels a secure rear base or supply lines before or during the first three years of war.

There is as yet too little evidence about the rebels' military expectations prior to rebellion to rule out the possibility that they initially expected to prevail without humanitarian intervention. If so, however, they suffered from substantial optimistic miscalculation, in light of the objective factors weighing against them. Moreover, given the likelihood of sparking state retaliation against their own civilians, the rebels would have had to accept in advance that such humanitarian suffering was a price worth paying.

After launching the rebellion, the only period when the rebels may have had reason for optimism was during the first few months of the war in 2003, when Khartoum attempted to negotiate and fought only half-heartedly by deploying lackluster army recruits while shunning the more motivated and vicious Arab militias. During this phase, "Eritrea welcomed the SLA and JEM to Asmara, and quickly became the main conduit for external support including fuel, food, and weapons," which enabled the rebels to make rapid progress. ${ }^{52}$ In mid-2003, however, Sudan's government switched to a scorched-earth counterinsurgency policy, embracing the Arab militias and quickly reversing the rebel gains.

After the summer of 2003, the rebels never again posed a substantial threat, even though Khartoum could not suppress them entirely because of terrain that was vast and sometimes inaccessible (which enabled one rebel faction to mount a small but disastrous attack toward the capital in 2008, as discussed below). As one member of the AU's 2006 mediation recalls: "The government regarded the rebels as unworthy military, political, and negotiating opponents: it believed that they did not pose a 
serious military threat." 53 In June 2006, the AU formally acknowledged this military imbalance in an extraordinary press statement directed at critics of the DPA: "An elementary reality, that sometimes appears to be lost on some commentators, is that the [rebel] Movements did not win a military victory and were therefore not in a position to impose their terms on the Government of Sudan." 54

In mid-2006, Darfur's rebels did receive a boost when Chad's President Deby, for domestic political reasons, finally aided them-but even this did not substantially alter the balance of power in Darfur. Deby had been besieged and nearly overthrown by Chadian rebels in April 2006, and so in desperation sought help from Darfur's JEM, after which he returned the favor by supporting the JEM and a faction of the SLA (combined briefly as the National Redemption Front), starting in spring $2006 .^{55}$ At roughly the same time, however, the rebels lost some support from a key backer, Eritrea, which had cut a deal with Khartoum on oil, trade, and security. Eritrea pressured Darfur's rebels to make concessions and arrested several senior officials of the SLA's Fur faction in June 2006, even reportedly torturing one of them. ${ }^{56}$ The JEM accordingly grew more powerful relative to the SLA and other splinter factions, and in May 2008 launched a small attack toward Khartoum. Within hours, however, Sudan's security forces had halted and decimated the attackers, revealing that although the JEM was now the most powerful rebel faction, it still was quite feeble. ${ }^{57}$

The rebels as a whole did not benefit from any significant increase in strength or prospect of victory in mid-2006. In fact, the signing of the DPA by one rebel faction, and internal disputes within all three factions over whether or not to sign, caused them to fracture and to begin fighting against each other, which further reduced their prospects against Khartoum. Some rebels still may have dreamed of prevailing without humanitarian intervention, perhaps envisioning an unlikely alliance with disgruntled local Arabs, ${ }^{58}$ but most senior rebels had long abandoned any such hopes. Indeed, most of the top rebel officials had been living abroad since 2004, rather than pursuing military victory in Darfur, as discussed in the following section.

The final question for Hypothesis 3 is whether the rebels rejected peace overtures after mid-2003 because they expected to acquire greater bargaining leverage in the future-not from humanitarian intervention-to compel more generous peace terms that would justify any interim costs. Although the rebels could not have expected to defeat Khartoum after mid-2003, they might have anticipated that an eventual boost in support from Chad, Eritrea, southern Sudan, or another strategic ally-or simply the perpetuation of a stalemate-would enable them eventually to extract concessions from Khartoum, while viewing the continued displacement and suffering of their own people as an acceptable price. This possibility cannot be excluded, although there is more evidence for Hypothesis 4, detailed in the next section.

To summarize, Darfur's militants had no reason to expect victory in the absence of humanitarian intervention, either prior to or after the first few months of rebellion, and must have expected massive retaliation against their own civilians. Still, the available evidence does not exclude the possibility that the rebels miscalculated wildly prior to and during the first few months of rebellion, expecting to prevail without intervention, while viewing retaliation against their civilians as an acceptable price of victory. After mid-2003, when the government implemented its brutally effective counterinsurgency, the rebels could not have expected to prevail without humanitarian intervention. But the available evidence does not exclude the possibility that the rebels continued to reject peace overtures because they anticipated that some other factor eventually would increase their bargaining leverage, while accepting the 
suffering of their own civilians in the meantime. Although there is little evidence for the third hypothesis, it cannot yet be rejected.

\section{Hypothesis 4: Gambling on Intervention?}

The evidence is strongest for the fourth hypothesis-that the expectation of humanitarian intervention caused both the initial rebellion and its perpetuation. As documented below, this expectation had four main sources: previous humanitarian intervention in southern Sudan; intervention elsewhere in the world since 1990; gradual intervention in Darfur, including by peacekeepers starting in 2004; and vocal international demands by states and non-governmental organizations for greater intervention in Darfur.

Darfur's initial rebellion was triggered mainly by the immediately preceding international intervention in Sudan that compelled Khartoum in 2002 to agree to share power and wealth with southern rebels. The international community had intervened because Khartoum's retaliation against the southern rebellion created a humanitarian emergency. The intervention included economic sanctions against Khartoum, support of the rebels, and pressure for cease-fires, in addition to more traditional relief operations. Although the South's civilians paid a terrible price during the southern rebellion, the humanitarian intervention ultimately rewarded the rebels and promoted their political agenda. The resulting 2005 peace agreement installed the rebels as political authorities in the newly autonomous southern Sudan, gave them considerable control over the south's rapidly growing oil revenue, and promised them a referendum on independence in six years. As Flint and DeWaal aptly note, the "agreement is a remarkably good deal for Southern Sudan." 59

Based on the southern rebels' achievements, Darfur's militants apparently inferred that they too would be rewarded with power and wealth if they launched a rebellion that provoked retaliation against civilians and thereby attracted humanitarian intervention. The evidence comes mainly from the reporting and inferences of Western experts close to Darfur's rebels. For example, Gérard Prunier observes, "It was largely the changes in the diplomatic north-south relationship which finally worked as an eye-opener for the young people of [Sudan's] west and drove them to take up arms."60 Khartoum's concessions toward the south had been compelled not by rebel strength but by intense international intervention. As Prunier notes, in the north-south negotiations, the "actors appeared driven to compromise more by American pressure than by any inner conviction that peace should actually be negotiated." ${ }^{61}$ Thus, the international community's well-intentioned humanitarian intervention in south Sudan had the tragic unintended consequence of encouraging rebellion in Darfur, which in turn provoked massive retaliation against civilians.

Unlike the competing hypotheses, moral hazard also explains the timing of Darfur's rebellion. The region's African tribes had opposed rebellion for decades, despite persistent grievances, until in 2002 they saw humanitarian intervention compel Khartoum to make substantial concessions to the southern rebels. Based on this precedent, DeWaal says, "Part of Darfur's non-Arab elite ... decided they could no longer wait on the sidelines of the north-south negotiations," and instead should launch their own rebellion. ${ }^{62}$

After Khartoum's brutal retaliation starting in mid-2003 eliminated any plausible rebel hope of victory on their own, the evidence shows that moral hazard-the expectation of humanitarian intervention-is also why the rebels kept fighting and rejecting government offers of compromise. By 2004, the SLA's two main leaders stopped even trying to lead their troops to victory in Darfur and instead went abroad seeking intervention. As Julie Flint writes: "Within a year of launching the rebellion, Abdel 
Wahid and Minawi were spending all their time outside Darfur, setting up headquarters in Asmara [Eritrea] and lobbying for international support and assistance. Fur leaders who had respected Abdel Wahid ... grumbled that he had become a 'hotel guerrilla." Indeed, for eighteen months from April 2004 to October 2005, Abdel Wahid did not set foot once in his ostensible rebel headquarters in central Darfur. Likewise, the SLA's Zaghawa leader, Minni Minawi, was denounced by subordinates for "command by remote control." 63

By spring 2004, however, the rebels' international lobbying had started to pay dividends, as the Darfur crisis became a humanitarian cause célèbre, spurring calls for intervention. Western media fostered support for the rebels by romanticizing them as freedom fighters who were defending their people against a premeditated, racially inspired genocide, even though the killing actually was a response to the uprising. A respected Sudanese commentator aptly observed: "As the rebellion grew, the main support for Darfur came from the international community, which provided humanitarian assistance to Darfurians and the logistics for the rebel movements to organize." 64

The African Union's initial military deployment, authorized in May 2004, comprised fewer than 450 personnel to oversee relief operations, but the broad array of humanitarian intervention ramped up steadily. ${ }^{65}$ In July 2004, the United Nations imposed an arms embargo on Darfur's Arab militias. In September 2004, the United States accused Sudan of genocide. In October 2004, the AU increased its authorized deployment to 3,320 personnel, and five months later to 7,731 personnel. In January 2005, a UN panel declared Sudan guilty of "serious violations of international human rights and humanitarian law." In March 2005, the UN expanded the arms embargo to encompass Sudan's government and referred Darfur to the International Criminal Court (ICC). In summer 2005, NATO approved logistical support to the AU peacekeepers. ${ }^{66}$ In May 2006, the United States successfully pressured Sudan to sign the Darfur Peace Agreement and then make further concessions. In July 2007, the United Nations authorized a joint UN-AU peacekeeping force (UNAMID) of 26,000 personnel. ${ }^{67}$ In March 2009, the ICC indicted Sudan's President al-Bashir for crimes against humanity and war crimes. (The UN Security Council has the authority to postpone the ICC prosecution but so far has not, apparently in hopes of deterring future violence against civilians. ${ }^{68}$ Contrary to these hopes, however, Sudan reacted to the indictment by expelling humanitarian aid groups-which it accused of collaborating with the court-thereby exacerbating Darfur's humanitarian suffering. The indictment, therefore, can be viewed as another element of humanitarian intervention that has backfired. $)^{69}$

Negotiations for the failed Darfur Peace Agreement of May 2006 demonstrate that at least two of the three rebel factions had continued to fight because they expected to benefit from additional humanitarian intervention. Minni Minawi, leader of the SLA's Zaghawa faction, agreed to sign only when the US negotiator, Deputy Secretary of State Robert Zoellick, convinced him that no further intervention would be forthcoming. The American official issued a blunt ultimatum: "I won't support any change in this document ... If you want to choose whoever, like JEM, you can do it-or you can choose the United States ... I am a good friend and I am a fearsome enemy."70 Minawi reluctantly acceded, explaining his decision the next day: "I calculated the balance of forces and I knew I had to sign." ${ }^{71}$ Just as the rebels had been emboldened by anticipated intervention, now Minawi was chastened by the loss of international support. As Fadul and Tanner observe, "Darfurians perceived a shift in international opinion ... [They] are assiduous listeners of ... Western radio broadcast 
services ... [and they] felt a growing international impatience with ... rebel intransigence."72

The SLA's Fur wing, which had fewer warriors than the Zaghawa wing and fewer resources than the JEM, was motivated even more than the others by the expectation of humanitarian intervention. As de Waal observes, "Abdel Wahid saw that his military option had closed, but he hoped for third-party military intervention in his favor." ${ }^{73}$ To address Abdel Wahid's security concerns, Zoellick presented a letter from US President George Bush assuring the rebel that-if he signed-the United States would guarantee the agreement. ${ }^{74}$ Then Zoellick issued an ominous warning: "If you pass up this historic opportunity, to whom do you intend to turn? If you pass this up you will remain victims forever." bluff, expecting that by rejecting the deal he could attract still more intervention. The rebel leader even told Zoellick what he anticipated: American and British intervention "like in Bosnia." 76 In that earlier Balkan conflict, the United States had helped arm and train the weaker side, launched air strikes to forge a peace deal, and then deployed peacekeepers. ${ }^{77}$ Abdel Wahid's comment reveals not only why he kept fighting - the expectation of humanitarian intervention-but how his expectation arose in part from a seemingly unrelated intervention a decade earlier and a continent away. It also demonstrates that he was willing to perpetuate the suffering of his own civilians as leverage to compel additional intervention in Darfur.

The third rebel faction, the JEM, had the least grass-roots support in Darfur at the time but the greatest external resources, initially from Islamist connections and, after spring 2006, from Chad. Accordingly, this faction's rejection of the DPA may not have been driven by expectations of humanitarian intervention.

All three rebel factions, consistent with the moral-hazard hypothesis, knowingly accepted massive retaliation against their own tribes as the price of achieving their political aims. Such callousness may be explained in part by a principal-agent dynamic: the African militants who agitated for rebellion were largely distinct from the African civilians who paid the price of retaliation. As Flint and DeWaal reveal, it was members of the Darfur diaspora, facing virtually no risk of retaliation, who led the charge for rebellion in 2001: "Zaghawa outside Darfur-expatriates in Libya, merchants and students in Khartoum-now agreed that there was a need to form an organized resistance." 78 Similarly, at the peace talks in 2006, the two rebel advisers who urged Abdel Wahid not to sign the DPA were "Canadians of Darfurian origin."79 Intertribal divides also played a role. In 2003, Zaghawa rebels attacked government forces in Fur territory, knowing that retaliation would fall on local Fur civilians, not fellow Zaghawa who lived far away. ${ }^{80}$ Within individual tribes, as well, there was disconnection between rebel leaders and the civilians whom they ostensibly represented. For example, Abdel Wahid rejected the DPA in 2006, even after Khartoum satisfied his security conditions, because he continued to demand greater sharing of wealth and power, even though Darfur's common "people always stressed these were secondary to security," according to field researchers. ${ }^{81}$ Even within his own delegation at the negotiations, "the majority was for signing, but Abdel Wahid refused to put the question to a vote." 82 As an AU negotiating-team member later complained bitterly, the international mediators "had always been guided by concern for the people of Darfur and responsibility for ending their suffering. None of the parties could have made any of these claims." 83

The above evidence demonstrates that two of Darfur's three rebel factions-the Fur and Zaghawa wings of the SLA-continued to fight in early 2006 only because their leaders expected additional humanitarian intervention. If not for such expecta- 
tions, it is reasonable to infer that these two factions previously would have agreed to peace, if they had rebelled at all. The rebellion thus would have been substantially diminished because the remaining rebel group, the JEM, enjoyed relatively little grass-roots support in Darfur during the first years of war. Khartoum's retaliatory violence against Darfur's African tribes, which was a direct response to the rebellion, logically should have been mitigated, too. The unavoidable implication is that the prospect of humanitarian intervention, as envisioned by the Responsibility to Protect, unintentionally exacerbated civilian suffering in Darfur.

\section{Hypothesis 5: Non-strategic Rebels?}

The final hypothesis contends that Darfur's militants were driven to rebel by something other than strategic calculation. Obviously, many factors-including ideological beliefs and past grievances-may have driven elements of Darfur's African tribes to desire change. But the relevant question for this study is whether such factors drove Darfur's African militants to embrace rebellion without-or despite-a strategic assessment of the likely consequences. No available evidence supports this hypothesis for the initial rebellion, which appears to have been a strategic attempt by Darfur's African militants to mimic the success of Sudan's southern rebels by attracting international intervention. In contrast, the perpetuation of Darfur's rebellion may be explained partly by several non-strategic dynamics. Overall, however, these explanations are less consistent with the evidence than the preceding moral-hazard hypothesis.

The literature on internal war explains that non-strategic action may arise partly from rebels being insufficiently consolidated to make unified decisions based on shared preferences. For example, rebels sometimes lack a "valid spokesperson," 84 so that rank-and-file rebels do not follow a leader's decisions. In September 2003, according to Prunier, the SLA's Zaghawa leader Minni Minawi agreed to a cease-fire and cantonment of weapons, but the truce "could not hold since the local guerrilla fighting units never accepted the cantonment principle." 85 A related explanation is "escalatory outbidding," in which rebel factions reject compromises that otherwise would be acceptable to them because they fear accusations of treason by other factions. ${ }^{86}$ During the 2006 DPA negotiations, says DeWaal, "the only way in which the two SLMs and JEM could adopt a united position at the peace talks was to agree on the most hardline stance." 87 A third such explanation stems from the principle-agent dynamic in which a rebel leader rejects a peace deal, despite it being favored by his constituents, because of personal concerns such as his own safety. ${ }^{88}$ Darfur's rebel leaders had reason for such concerns considering that in March 2003, when they agreed to a brief cease-fire, Arab militias attacked and killed the most senior Masalit sheikh. ${ }^{89}$

Non-strategic dynamics also can result from rebels acting irrationally. For example, militants may be driven by emotions of vengeance, based on past grievances, to rebel without contemplating the consequences. Flint and DeWaal offer anecdotes of Darfur rebels who ostensibly were driven by such emotions. ${ }^{90}$ In addition, senior militants may suffer from psychiatric disorders. This possibility was raised by the Libyan representative at the DPA negotiations, who alleged that the JEM's leader, Khalil Ibrahim, was simply "mad."91 Finally, one AU mediator claims that the rebels were "frightened of being outwitted in the negotiations," because they had little experience in high-level bargaining, and so rejected deals that actually were in their rational interest. ${ }^{92}$

Many or all of these non-strategic dynamics may have helped perpetuate the rebellion. But in May 2006, none of these factors prevented the most powerful rebel faction's leader, Minni Minawi, from signing the Darfur Peace Agreement. His deci- 
sion spurred the defection of some subordinates and was criticized as treason by other factions, but he nevertheless signed when he judged that no further intervention was forthcoming. In return, the government honored its pledge to ally with his forces and appoint him as senior assistant to the president of Sudan. This demonstrates that even though Darfur's militants were not consolidated, rebel leaders still could act rationally, abandoning rebellion when peace offered greater rewards.

Although non-strategic factors affected the rebels, their most fateful actions are better explained by strategic calculation. For example, even though vengeful emotions mounted during the first three years of war, Minawi still was able to sign the DPAindeed, mere hours after learning that his own brother had been killed in the fighting. Khalil might have been "mad," but he also had rational reasons to reject the DPA: the agreement failed to address the JEM's national agenda, and his rebel group could sustain itself with support from Islamist sources and Chad. ${ }^{93}$ Abdel Wahid's rejection is best explained not by irrationality but by his expressed strategic assessment that he could hold out for greater intervention "like in Bosnia." (This calculation appears to have been wrong, perhaps resulting from imperfect information or motivated bias, which often cause strategic decisions to be suboptimal.) Finally, although the rebels initially may have lacked experience in high-level negotiations, by the time of the DPA they were advised by senior diplomats from African and Western states, which helped to level the bargaining table. Diplomatic inexperience did not stop Sudan's southern rebels from signing a peace agreement in 2005, nor Minawi from signing the DPA the following year. The non-strategic factors above may have inhibited the rebels from quick and efficient decision-making but did not prevent them from acting strategically on key decisions of war and peace.

\section{Summary and Conclusions}

In an effort to explain Darfur's rebellion since 2003, the first rigorous test of competing hypotheses finds strong evidence for moral hazard (Hypothesis 4). The expectation of humanitarian intervention explains when and why Darfur's African militants launched their rebellion, and why they persisted in the face of massive state-sponsored retaliation against their own civilians despite little apparent chance of victory. Darfur's rebels aimed to repeat the success of southern Sudan's rebels in attracting humanitarian intervention to compel Khartoum to share wealth and power. Darfur's militants launched the rebellion in 2003, immediately after seeing the south's rebels rewarded in a 2002 peace protocol that resulted from intense international pressure on Khartoum. After Darfur's rebellion provoked massive retaliation against local African tribes, the leaders of the main rebel group ceased attempting to command their forces to victory and instead went abroad to lobby for humanitarian intervention. In 2006, the leader of the SLA's Zaghawa wing agreed to peace when he was persuaded by a senior American official that no further intervention was forthcoming. The leader of the SLA's Fur wing rejected that peace deal because he still expected more robust humanitarian intervention "like in Bosnia." The other rebel group of the time, the JEM, had national ambitions and other sources of external support, especially after spring 2006, so the moral-hazard hypothesis may not explain as fully its rebellion. The sources of moral hazard in Darfur-that is, the reasons the rebels expected to benefit from humanitarian intervention-are similar to those identified by Crawford and include the following: previous intervention in other countries, including the Bosnia precedent cited explicitly by the founder of Darfur's main rebel group; recent and nearby intervention in Sudan's north-south civil war; gradual escalation of intervention in Darfur starting with humanitarian aid in 2003 and peacekeepers in 2004; 
Table 2: Assessing Explanations for Darfur's Suicidal Rebellion

\begin{tabular}{lll}
\hline Hypothesis & Initiation & Perpetuation \\
\hline Do not expect retaliation & No & No \\
Perceive victimization as inevitable & No & No \\
Expect victory without intervention & $?$ & (through May 2006) \\
Expect intervention to enable victory & Probably & Probably \\
Not driven by strategic calculus & (SLA especially) & (SLA especially) \\
\hline
\end{tabular}

and persistent calls by Western states and non-governmental organizations for greater intervention in Darfur.

Competing explanatory hypotheses are not as well supported, but some cannot be rejected for certain periods of Darfur's rebellion based on available evidence (see Table 2). Hypothesis 1 is refuted because Darfur's militants had overwhelming reason to expect that rebellion would provoke retaliation against their own civilians based on past experience in Darfur and elsewhere in Sudan. Regarding Hypothesis 3, it is possible that the rebels initially expected to win without humanitarian intervention during the first months of 2003, or that following the government's devastating retaliation the rebels still expected to extract future concessions from Khartoum, but there is little if any supporting evidence. In the wake of brutal retaliation, the rebels may have been inhibited from strategic decision making (Hypothesis 5) by lack of consolidation, desire for vengeance, and inexperience in negotiation, but these factors were not decisive because the strongest rebel faction at the time still managed to embrace peace in 2006. When the other two rebel factions rejected the DPA in May 2006, and Darfur descended into anarchy, the rebellion may have been prolonged by a newfound perception among the region's African tribes that violence had become unavoidable (Hypothesis 2). But no such perception can explain the preceding three years of rebellion.

As with any claim about causality, assessing the impact of moral hazard in Darfur involves a counter-factual thought experiment. Simply put, if not for the expectation of humanitarian intervention, would there have been a rebellion, would it have been as large and protracted, and would it have provoked as much violence against civilians? ${ }^{94}$ The findings above suggest that, even without the prospect of humanitarian intervention, Darfur still might have experienced small-scale intergroup skirmishes over land, water, and livestock. But Darfur's African tribes would have been unlikely to escalate to full-blown rebellion because, without an expectation of intervention, such rebellion was widely perceived as counter productive, if not suicidal.

If Darfur's militants had suffered from severe optimistic miscalculation, they still might have launched a rebellion. But without an expectation of intervention, the government's initial brutal retaliation likely would have compelled the SLA to accept peace in the first year, because the subsequent evidence indicates that both factions of this rebel group continued fighting only in hopes of attracting such intervention. The JEM might have fought on because of its national agenda and external sources of support but, in light of its initially weak grass-roots support in Darfur, this sole rebel faction would not have represented as significant a threat. Considering that 
Khartoum escalated its retaliation against civilians only after the rebels escalated their own attacks in 2003, a smaller rebellion probably would have provoked less retaliatory violence against civilians. ${ }^{95}$ Although no counter-factual scenario ever can be proved definitively, the evidence suggests that moral hazard-the expectation of humanitarian intervention-increased both the magnitude and duration of Darfur's rebellion, and therefore the retaliation it provoked against civilians.

This study represents an initial effort to assess rigorously the moral hazard of humanitarian intervention in Darfur. Further research is required to assess more precisely the expectations and motivations of Darfur's militants prior to and during their rebellion, in order to determine with greater confidence the relative explanatory power of Hypotheses 3 and 4. Moreover, to address the concern raised by Grigorian in a previous case, additional research should explore whether international intervention in Darfur actually was driven by humanitarian concerns, as this study assumes, or by other goals such as changing Khartoum's regime.

In previous work, I have recommended modifying how the Responsibility to Protect is implemented to reduce its perverse, unintended consequences and to foster its intent of protecting civilians. ${ }^{96}$ The essence of my proposal is that intervention should not reward rebels, unless state retaliation is grossly disproportionate, but rather should aim to induce states to address the legitimate grievances of nonviolent domestic groups. Had this policy guided intervention in 2003, and had Khartoum nonetheless perpetrated its grossly disproportionate retaliation to the Darfur rebellion, then intervention to aid the rebels would have been called for. But this policy also might have deterred Khartoum from perpetrating disproportionate retaliation, hoping to avert intervention, or dissuaded Darfur's militants from rebelling in the first place by reducing their expectation of benefiting from intervention, so that they instead pursued non-violent resistance.

Some skeptics may reject non-violent protest as useless against a state that is willing to brutalize defenseless civilians in response to rebellion, but historical evidence suggests that it can work in Sudan. In 1985, for example, protests by Sudanese who had been displaced by famine helped end the authoritarian rule of President Jaafar Nimeiri. In 1988, nonviolent demonstrations persuaded Sudan's government to continue bread subsidies and "to begin taking seriously the conflict in Darfur," according to a former Darfur government official. ${ }^{97}$ The Responsibility to Protect should be implemented in ways that promote such non-violent paths to progress in Sudan and elsewhere, rather than encouraging rebellion that provokes genocidal retaliation.

\section{Acknowledgements}

The author is grateful for comments from Costantino Pischedda and three anonymous referees and for financial support from the Policy Research Institute at the LBJ School of Public Affairs, University of Texas at Austin.

\section{Notes}

1. See, most recently, Alan J. Kuperman, "Rethinking the Responsibility to Protect," Whitehead Journal of Diplomacy and International Relations 10 (2009): 33-43.

2. Ibid.

3. Alan J. Kuperman, "The Moral Hazard of Humanitarian Intervention: Lessons from the Balkans," International Studies Quarterly 52 (2008): 49-80, 52.

4. See Kuperman, ibid., which also reviews previous literature on this subject. 
5. Alan J. Kuperman, review of The Responsibility to Protect: Ending Mass Atrocity Crimes Once and for All, by Gareth Evans, Political Science Quarterly 124 (2009): 590-91.

6. Alan J. Kuperman, "Mitigating the Moral Hazard of Humanitarian Intervention: Lessons from Economics," Global Governance 14 (2008): 219-40.

7. Timothy W. Crawford, "Moral Hazard, Intervention and Internal War: A Conceptual Analysis," in Gambling on Humanitarian Intervention: Moral Hazard, Rebellion and Civil War, ed. Timothy Crawford and Alan J. Kuperman (New York: Routledge, 2006), 26-44.

8. Jon Western, "Illusions of Moral Hazard: A Conceptual and Empirical Critique," in Gambling on Humanitarian Intervention: Moral Hazard, Rebellion and Civil War, ed. Timothy Crawford and Alan J. Kuperman (New York: Routledge, 2006), 74-85.

9. Arman Grigorian, “Third-party Intervention and Escalation in Kosovo: Does Moral Hazard Explain It?" in Gambling on Humanitarian Intervention: Moral Hazard, Rebellion and Civil War, ed. Timothy Crawford and Alan J. Kuperman (New York: Routledge, 2006), 45-63.

10. R. Harrison Wagner, "The Hazards of Thinking about Moral Hazard," in Gambling on Humanitarian Intervention: Moral Hazard, Rebellion and Civil War, ed. Timothy Crawford and Alan J. Kuperman (New York: Routledge, 2006), 86-96.

11. The best methodological analysis to date is Kelly Whitty, "Darfurian Rebel Leaders and the Moral Hazard of Humanitarian Intervention," Paterson Review 9 (2008): 19-34. The article details how the moral-hazard hypothesis could be tested against alternative explanations for the rebellion in Darfur but by its own admission does not conduct such a rigorous test. Based on a brief review of evidence, Whitty concludes that "there is preliminary evidence to support the hypothesis that the Darfurian rebel leadership launched a suicidal rebellion against the government of Sudan with the intention of provoking retaliation against their own people. The ensuing humanitarian catastrophe was meant to garner international attention and intervention as a means to advance their political objectives ... Evidence therefore suggests Kuperman's theory of moral hazard accurately describes the case study of the Darfur rebellion" (20). Previous analyses consistent with this hypothesis include the following: Sam Dealey, "Misreading the Truth in Sudan," New York Times, 8 August 2004, 4:11; Samantha Power, "Dying in Darfur," New Yorker, 30 August 2004, 56-73; Morton Abramowitz and Samantha Power, "A Broken System," Washington Post, 13 September 2004; International Crisis Group, "Darfur: The Failure to Protect," Africa Report, 8 March 2005, 9; Scott Anderson, "How Did Darfur Happen?" New York Times Magazine, 17 October 2004, 52ff; Alan J. Kuperman, "Next Steps in Sudan," Washington Post, 28 September 2004, A27; Alan J. Kuperman, "Strategic Victimhood in Sudan," New York Times, 31 May 2006, 19; Roberto Belloni, "The Tragedy of Darfur and the Limits of the "Responsibility to Protect," Ethnopolitics 5 (2006): 327-46; Mahmood Mamdani, "The Politics of Naming: Genocide, Civil War, Insurgency," London Review of Books, 8 March 2007, http://www.lrb.co.uk/v29/n04/mamd01_html (accessed 22 September 2009).

12. Stephen Van Evera, Guide to Methods for Students of Political Science (Ithaca, NY: Cornell University Press, 1997). See also, Marc Trachtenberg, The Craft of International History: A Guide to Method (Princeton: Princeton University Press, 2006).

13. Alan J. Kuperman, "Suicidal Rebellions and the Moral Hazard of Humanitarian Intervention," in Timothy W. Crawford and Alan J. Kuperman, eds., Gambling on Humanitarian Intervention: Moral Hazard, Rebellion and Civil War (New York: Routledge, 2006), 1-25. See also, Kuperman, "The Moral Hazard of Humanitarian Intervention: Lessons from the Balkans."

14. A fuller discussion of the conflict's roots was deleted from this article for reasons of space, but may be obtained by contacting the author.

15. Julie Flint and Alex de Waal, Darfur: A Short History of a Long War (New York: Zed Books, 2005), 25, 57; and Gérard Prunier, Darfur: The Ambiguous Genocide (Ithaca, NY: Cornell University Press, 2005), 73. 
16. Prunier, Darfur: The Ambiguous Genocide, 92-96; Flint and de Waal, Darfur: A Short History, 71, 77, 83; and Julie Flint, "Darfur's Armed Movements," in War in Darfur and the Search for Peace, ed. Alex de Waal (Cambridge, MA: Harvard University Press, 2007), 150.

17. Prunier, Darfur: The Ambiguous Genocide, 92-96. Flint and de Waal, Darfur: A Short History, 99-104, claim that from April to July 2003 the rebels won thirty-four of thirty-eight military engagements.

18. Prunier, Darfur: The Ambiguous Genocide, 95.

19. Debarati Guha-Sapir and Olivier Degomme, "Counting the Deaths in Darfur: Estimating Mortality from Multiple Survey Data" (working paper, Households in Conflict Network, 15 April 2006), http://www.hicn.org/papers/wp15.pdf (accessed 16 July 2009). Their conservative analysis estimates 112,000 excess deaths-including approximately 35,000 resulting directly from violence-in Darfur between September 2003 and January 2005, a timeframe that encompasses most of the war's intense violence and the resulting humanitarian deprivation prior to the institutionalization of aid provision. Death rates after this period were much lower, sometimes beneath the normal peacetime death rate in Darfur. See Fabrice Weissman, "Humanitarian Dilemmas in Darfur," Médecins sans frontières (July 2008), 7-8, http://www.msf.fr/drive/214a9aa0483c6e560e05cdafb00beb11.pdf (accessed 16 July 2009). Other death estimates are up to several times higher but based on less conservative assumptions. See John Hagan and Alberto Palloni, “Death in Darfur," Science, 15 September 2006, 1578-79.

20. Prunier, Darfur: The Ambiguous Genocide, 106-108.

21. Nima Elbagir, "W. Sudan Rebels Say Unlikely To Go To Peace Talks," Reuters (15 April 2004), http://www.sudantribune.com/spip.php?article2501 (accessed 16 July 2009); "Darfur Rebels Reject Invitation To Hold Talks with Sudan's Govt in Ethiopia," Sudan Tribune (22 May 2004), http://www.sudantribune.com/spip.php?article3022 (accessed 16 July 2009); Opheera McDoom, "Darfur Rebels Won't Attend Peace Talks," Reuters (2 July 2004), http://www.swissinfo.ch/eng/index.html?siteSect=143\&sid=5056075 (accessed 16 July 2009); Anderson, in "How Did Darfur Happen?" noted in October 2004: "In recent months, the SLA has repeatedly stalled peace talks being brokered by the African Union by setting unrealistic preconditions or quibbling over such details as where the talks should be held; for its part, the [JEM] had, until recently, boycotted the talks altogether."

22. Dawit Toga, "The African Union Mediation and the Abuja Peace Talks," in War in Darfur and the Search for Peace, ed. Alex de Waal (Cambridge, MA: Harvard University Press, 2007), 214-44.

23. Flint and de Waal, Darfur: A Short History, 95-96, suggests this hypothesis: "In the first months of 2003, these half-formed and inexperienced rebel fronts were catapulted out of obscurity to face challenges for which they were totally unprepared. They should perhaps have had more foresight."

24. Ibid., 98; Prunier, Darfur: The Ambiguous Genocide, 91-93.

25. Flint and de Waal, Darfur: A Short History, 24-25; Alex de Waal, "Sudan: The Turbulent State," in War in Darfur and the Search for Peace, ed. Alex de Waal (Cambridge, MA: Harvard University Press, 2007), 6.

26. Flint and de Waal, Darfur: A Short History, 25, 57; Prunier, Darfur: The Ambiguous Genocide, $73-75,87$.

27. Flint and de Waal, Darfur: A Short History, 64, 77, 81.

28. Ibid., 72 .

29. Ibid., 75 .

30. Abdul-Jabbar Fadul and Victor Tanner, "Darfur after Abuja: A View from the Ground," in War in Darfur and the Search for Peace, ed. Alex de Waal (Cambridge, MA: Harvard University Press, 2007), 288.

31. Flint and de Waal, Darfur: A Short History, 80, 98, 101-104; Prunier, Darfur: The Ambiguous Genocide, 96-97.

32. Prunier, Darfur: The Ambiguous Genocide, 109. 
33. Flint and de Waal, Darfur: A Short History, 116, citing interviews in the Masalit area in March-April 2004. (The book's footnotes in that chapter are off by one. Personal communication with Julie Flint, 7 January 2009.)

34. Flint and de Waal, Darfur: A Short History, 66, 69, 71.

35. Flint, "Darfur's Armed Movements," 146.

36. Flint and de Waal, Darfur: A Short History, 58-60, 63, 72-73; Flint, "Darfur's Armed Movements," 144, 147.

37. Prunier, Darfur: The Ambiguous Genocide, 74-75; Flint and de Waal, Darfur: A Short History, 58-60.

38. Flint and de Waal, Darfur: A Short History, 63.

39. Flint, "Darfur's Armed Movements," 144.

40. Prunier, Darfur: The Ambiguous Genocide, 88; Flint and de Waal, Darfur: A Short History, $77,81$.

41. Flint, "Darfur's Armed Movements," 148, referring to Ahmad Diraige.

42. Fadul and Tanner, "Darfur after Abuja," 288.

43. Adam Azzain Mohammed, "The Comprehensive Peace Agreement and Darfur," in War in Darfur and the Search for Peace, ed. Alex de Waal (Cambridge, MA: Harvard University Press, 2007), 210.

44. Fadul and Tanner, "Darfur after Abuja," 293. This suggests that at this point Darfurians may have believed that government-sponsored violence against civilians was not inevitable because the international peacekeepers to be deployed under a peace agreement could stop it.

45. Toga, "The African Union Mediation," 242-43. Rebel faction leader Abdel Wahid demanded greater representation in the legislative and executive branches at the state and local level of government, and an increase in initial compensation from $\$ 30$ to $\$ 200$ million. Khartoum refused to make such concessions at the time. See also, Alex de Waal, "Darfur's Deadline: The Final Days of the Abuja Peace Process," in War in Darfur and the Search for Peace, ed. Alex de Waal (Cambridge, MA: Harvard University Press, 2007), 267-76, who notes that earlier in May 2006, US negotiators had obtained another concession on security from the government-a pledge to retrain 3,000 rebels in addition to integrating 5,000 into the government's forces-which helped persuade rebel faction leader Minni Minawi to sign the DPA. Even prior to the government's concessions on security, Abdel Wahid's demands to Zoellick for modification of the DPA on 5 May 2006 focused mainly on other concerns: "The document must be developed, in the fields of power sharing and compensation" (35). Alex de Waal, "The Book Was Closed Too Soon on Peace in Darfur," The Guardian (29 September 2006), http://www.guardian.co.uk/commentisfree/ 2006/sep/29/comment.sudan (accessed 15 October 2009), reports that de Waal "was present in the final negotiating session when Wahid declared the DPA's security arrangements 'acceptable.",

46. Fadul and Tanner, "Darfur after Abuja," 288. The interviewees were mainly men. Women reportedly still opposed the rebellion. An anonymous reviewer reports that in unpublished field research conducted during 2007-2008, some of Darfur's African tribes were willing to abandon rebellion if UN peacekeepers provided adequate protection.

47. Geoffrey Blainey, The Causes of War, 3rd ed. (New York: Free Press, 1988).

48. Jerome Tubiana, "Darfur: A War for Land?" in War in Darfur and the Search for Peace, ed. Alex de Waal (Cambridge, MA: Harvard University Press, 2007), 72. In Darfur: The Ambiguous Genocide, 82-87, Prunier says Turabi arranged weapons from Eritrea and from the southern rebels for the JEM as early as 2001. Flint, in "Darfur's Armed Movements," 144,147 , says that the southern rebels provided the SLA a satellite phone in late 2002, and then heavy rifles and anti-aircraft artillery in early 2003 by air shipment to Zaghawa territory in north Darfur. This account also says that Eritrea began providing weapons in early 2003. The supply of weapons to the rebels is also reported in United Nations, Report of the Panel of Experts established pursuant to paragraph 3 of resolution 1591 (2005) concerning the Sudan, UN DOC S/2006/65 (30 January 2006), 28.

49. Flint and de Waal, Darfur: A Short History, 75. 
50. Paul Staniland, "Defeating Transnational Insurgencies: The Best Offense Is a Good Fence," Washington Quarterly 29 (2005-2006): 21-40.

51. Flint, "Darfur's Armed Movements," 149.

52. Ibid., 150.

53. Laurie Nathan, "The Making and Unmaking of the Darfur Peace Agreement," in War in Darfur and the Search for Peace, ed. Alex de Waal (Cambridge, MA: Harvard University Press, 2007), 255.

54. African Union, "African Union Responds to International Crisis Group Report of 20 June 2006 'Darfur's Fragile Peace Agreement'” (Press Release), http://www.africa-union.org/ root/ua/Actualites/2006/juin/PR_AU_ICG_Report_23_06_06.pdf (accessed 13 February 2009).

55. Flint, "Darfur's Armed Movements," 151; Alex de Waal, "Prospects for Peace in Darfur," in War in Darfur and the Search for Peace, ed. Alex de Waal (Cambridge, MA: Harvard University Press, 2007), 373.

56. de Waal, "Prospects for Peace in Darfur," 384-86.

57. Stephanie McCrummen, "Incursion Crushed, Sudan Reports," Washington Post, 11 May 2008, A1; Jeffrey Gettleman, "After a Quixotic Attack in Sudan, a Question Lingers: Why?" New York Times, 12 May 2008, A6.

58. de Waal, "Prospects for Peace in Darfur," 387.

59. Flint and de Waal, Darfur: A Short History, 32.

60. Prunier, Darfur: The Ambiguous Genocide, 79.

61. Ibid., 89 .

62. Tubiana, "Darfur: A War for Land?" 72.

63. Flint, "Darfur's Armed Movements," 154-55. Flint and de Waal, in Darfur: A Short History, 87, observe that "instead of building their political cadres, the SLA's leaders became ambassadors."

64. Ahmed Kamal El-Din, "Islam and Islamism in Darfur," in War in Darfur and the Search for Peace, ed. Alex de Waal (Cambridge, MA: Harvard University Press, 2007), 109.

65. Prunier, Darfur: The Ambiguous Genocide, 116-19. The initial authorization was for 300 peacekeepers and 132 military observers (including 60 from the AU). For background information, see http://www.amis-sudan.org/history.html. Sudan and the rebels approved this deployment in an agreement on 28 May 2004. The first military observers arrived in June 2004. Full deployment to authorized levels typically lagged behind authorization by six to twelve months.

66. Belloni, "The Tragedy of Darfur," 337-39. See also, http://www.amis-sudan.org/history. html.

67. United Nations, "Darfur-UNAMID—Facts and Figures," http://www.un.org/depts/dpko/ missions/unamid/facts.html (accessed 23 December 2008).

68. "Braced for the Aftershock," Economist, 7 March 2009, reported that a potential UN deferral was opposed by those who "fear the return to a "climate of impunity." See http:// www.economist.com/world/international/.

69. Lynsey Addario and Lydia Polgreen, "Aid Groups' Expulsion, Fears of More Misery," New York Times, 23 March 2009, A6. Although unintended, these negative consequences were foreseeable. See Alan J. Kuperman, “Ocampo and Bashir: The Milosevic Precedent," SSRC Blogs, Making Sense of Darfur (23 June 2008), http://www.ssrc.org/blogs/darfur/2008/06/ 23/ocampo-and-bashir-the-milosevic-precedent/.

70. de Waal, "Darfur's Deadline," 273. US negotiators had successfully pressured Khartoum to make multiple concessions to the rebels. In this light, Zoellick's statement presumably intended to convey to Minawi that no further such assistance to the rebels would be forthcoming, not that the United States actually would ally with Khartoum against the rebels.

71. de Waal, "Prospects for Peace in Darfur," 376.

72. Fadul and Tanner, "Darfur after Abuja," 293.

73. de Waal, "Prospects for Peace in Darfur," 373.

74. de Waal, "Darfur's Deadline," 274. 
75. Ibid., 274, 277. After Abdel Wahid rejected the agreement, Zoellick tried one last time to persuade him that the ultimatum was sincere: "If you think there is an alternative, you are dead wrong. And I mean, dead wrong ... You are making a decision; you will live with it and you will die with it."

76. de Waal, "Darfur's Deadline," 276. See also, de Waal, "Prospects for Peace in Darfur," 379-80: "Along with American activists, Darfurians had inflated hopes and fears for what UN troops might be able to do. When Abdel Wahid al Nur demanded guarantees "like Bosnia' in the early hours of May 5 [2006], this is what he had in mind." See also, 376: "The vision of international troops bringing safety to Darfurian victims of genocide complicated the search for peace."

77. For a case study of the Bosnia intervention, see Alan J. Kuperman, "Humanitarian Intervention," in Human Rights: Politics and Practice, ed. Michael Goodhart (Oxford: Oxford University Press, 2009), 334-53.

78. Flint and de Waal, Darfur: A Short History, 75.

79. de Waal, "Prospects for Peace in Darfur," 373, 412.

80. Flint and de Waal, Darfur: A Short History, 86.

81. Fadul and Tanner, "Darfur after Abuja," 286.

82. de Waal, "Darfur's Deadline," 279.

83. Nathan, "The Making and Unmaking of the Darfur Peace Agreement," 266.

84. I. William Zartman, Elusive Peace (Washington, DC: Brookings Institution, 1995), 23, 340.

85. Prunier, Darfur: The Ambiguous Genocide, 106-108.

86. Fred Charles Ikle, Every War Must End, rev. ed. (New York: Columbia University Press, 1991); Donald Horowitz, "Making Moderation Pay," in Conflict and Peacemaking in Multiethnic Societies, ed. Joseph V. Montville (New York: Lexington Books, 1991).

87. de Waal, "Prospects for Peace in Darfur," 373; Nathan, "The Making and Unmaking of the Darfur Peace Agreement," 258, notes a further complication that may have exacerbated the outbidding: "JEM had a national political agenda that would not be met by a peace agreement for Darfur." See also, Prunier, Darfur: The Ambiguous Genocide, 122.

88. Graham T. Allison and Morton H. Halperin, "Bureaucratic Politics: A Paradigm and Some Policy Implications," World Politics 24, Supplement: Theory and Policy in International Relations (1972), 40-79.

89. Flint and de Waal, Darfur: A Short History, 98.

90. Ibid., 67-68.

91. de Waal, "Darfur's Deadline," 275.

92. Nathan, "The Making and Unmaking of the Darfur Peace Agreement," 257.

93. de Waal, "Darfur's Deadline," 274-75, details the JEM's numerous complaints about the DPA.

94. James Fearon, "Counterfactuals and Hypothesis Testing in Political Science," World Politics 43 (1991): 169-95.

95. It is possible that Khartoum was deterred from greater violence by the threat of intervention. In light of such potential dynamics, my proposed policy calls for intervention to help rebels in the event of "grossly disproportionate" state retaliation, to deter excessive state violence.

96. Kuperman, "Mitigating the Moral Hazard of Humanitarian Intervention"; Kuperman, "Rethinking the Responsibility to Protect."

97. Mohammed, "The Comprehensive Peace Agreement and Darfur," 202. 